\title{
U-Pb ZIRCON DETERMINATIONS FROM THE KEIKYÄ BRECCIA AND OTHER SITES IN THE SVECOFENNIDES: INDICATIONS OF A SVECO- KARELIAN PROTOCRUST
}

\author{
MATTI VAASJOKI, KIMMO PIETIKÄINEN and MARKUS VAARMA
}

\begin{abstract}
MATTI VAASJOKI, KIMMO PIETIKÄINEN and MARKUS VAARMA, 1996: U-Pb zircon determinations from the Keikyä Breccia and other cites in the Svecofennides: indications of a Svecokarelian protocrust. Bull. Geol. Soc. Finland 68, Part 1, 3-10.

Heterogeneous zircon populations from four different localities within the Svecofennian area in Finland demonstrate that the ca. 1890 Ma old syntectonic granitoids contain older material, probably belonging to the ca. $1950 \mathrm{Ma}$ Svecofennian protocrust, the influence of which is also evident in metaturbidites deformed by the Svecokarelian orogeny.
\end{abstract}

Key words: breccia, quartz diosites, gabbros, tonolite, absolute age, U/Pb, zircon, Proterozoic, keikyä, Kalliokari, Evijärvi, Finland

Matti Vaasjoki, Geological Survey of Finland, FIN-02150, Espoo, Finland Kimmo Pietikäinen, Geological Survey of Finland, FIN-02150, Espoo, Finland

Markus Vaarma, Geological Survey of Finland, FIN-02150, Espoo, Finland

\section{INTRODUCTION}

The intrusive breccia at Keikyä (Fig. 1) has been known as an attractive excursion site ever since its discovery during regional mapping over 30 years ago (cf. Matisto, 1964 and 1976). It consists of two principal rock types: 1) a horblende-biotite quartzdiorite, which contains tonalitic and gabbroic enclaves, and is brecciated by 2) a hornblende gabbro, which does not show any marked signs of deformation. Regionally the rocks form part of the Kylmäkoski-Vammala-Pori zone, which is charac- terized by numerous mafic-ultramafic intrusions hosting nickel mineralization. These rocks have been dated at the Vammala Ni-ore deposit to be $1890 \mathrm{Ma}$ in age (Häkli et al., 1979).

A relatively new finding concerning the Proterozoic evolution of the Fennoscandian Shield has been the realization that the Svecokarelian orogeny, which culminated about $1890 \mathrm{Ma}$ ago, was a rapid process, with syn-, late- and posttectonic rocks in central Finland being essentially coeval within the experimental error of zircon datings (Vaasjoki and Sakko, 1988). Another new fact has 


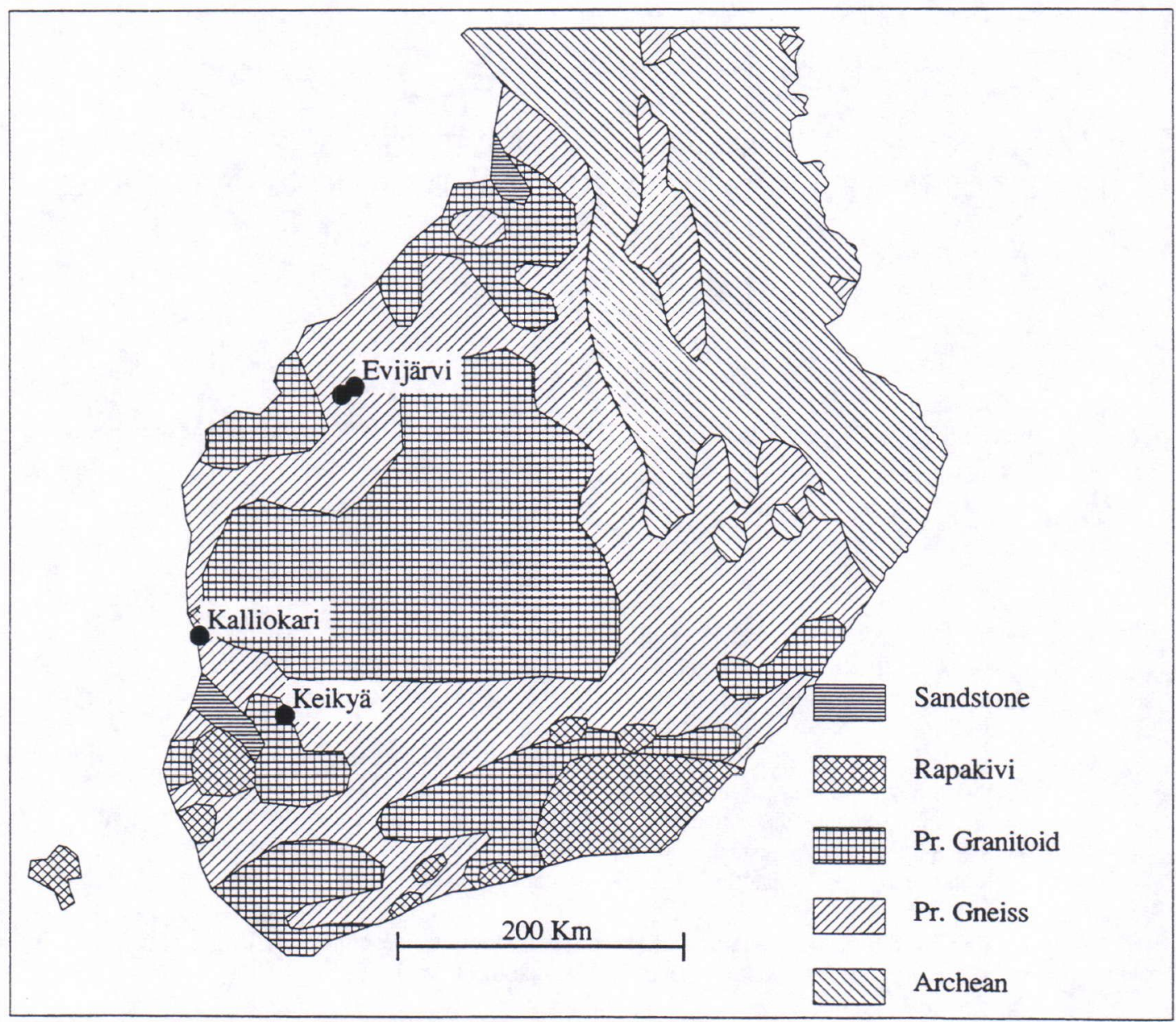

Figure 1. Geographical locations of the Keikyä breccia, the tonalite from Kalliokangas and the granitoid samples from the Evijärvi map sheet area.

been the discovery that Svecofennian turbiditic sediments contain bimodal detrital zircon populations, with a minor Archean component and a dominant one registering ages in the range of 1900-2000 Ma (Huhma et al. 1991). Considering the wide distribution of these metasediments over the central part of the Fennoscandian Shield (Claesson et al. 1993), it is obvious that their provenance must have contained a large proportion of what has tentatively been called a Svecokarelian protocrust.

However, apart of the data gleaned from the metasediments, there is very little direct evidence on the existence and extent of the supposed protocrust. Although a number of Svecokarelian granitoids register ages in the order of 1910-1930 Ma (e.g. Helovuori, 1979; Vaasjoki and Sakko, 1988), and the Rastinpää tonalite at Pielavesi in particular demonstrates the existence of a metamorphic event prior to the main Svecokarelian event (Korsman et al., 1984), they are volumetrically small and cannot have produced sufficient material for the metaturbidites. On the other hand, recent Sm-Nd data (Huhma and Lahtinen, 1993) demonstrate that these granitoids are juvenile crust derived from mantle material and would therefore be likely 
components of a Svecokarelian protocrust, particularly if they are considered a result of melting of island arc volcanics (Lahtinen, 1994).

Regional mapping (Matisto, 1976) has demonstrated that the mutual relationships of the two principal rock types of the Keikyä breccia form quite an exception because in general, the more mafic rocks are brecciated by granitoids which can be considered syntectonic with respect to the Svecokarelian orogeny. It was thus feasible to assume that, as gabbros in the Kylmäkoski-Vammala-Pori zone have been demonstrated to be ca. $1890 \mathrm{Ma}$ old, the quartzdiorite fragments of the Keikyä breccia were likely candidates to be part of an older group of granitoids, possibly representing the hypothetical Presvecokarelian protocrust.

Although the Keikyä breccia presently is a unique occurrence, data which can be interpreted along similar lines of thought have been accumulated in recent years from some Svecofennian granitoids. We therefore report in this context also results from three tonalite occurrences exhibiting heterogeneous zircon populations.

\section{SAMPLE MATERIAL}

\section{The Keikyä breccia}

The quartzdiorite forming the fragments within the Keikyä breccia consists principally of medium grained $(2-5 \mathrm{~mm})$ euhedral, somewhat zoned plagioclase $\left(\mathrm{An}_{40}\right)$, and approximately equal amounts of hornblende, biotite and quartz as the other major minerals. Accessory minerals are epidote, apatite, opaques and zircon in that order. The zircon is quite fine-grained (over $80 \%$ $<70$ microns), exhibits quite strong oscillatory zoning and has a median length/breadth ratio of 2. Simple prismatic and pyramidal crystal forms are dominating, but faces with higher order indeces occur as well. The color is generally pale brown, but occasional darker crystals have been observed. Under air the zircons are translucent, and examination under oil immersion revealed that they do not contain visible older cores.
The brecciating gabbro is of a slightly finer grain size (1-2 mm), the most abundant mineral being euhedral greenish hornblende, which is often accompanied by another, colorless amphibole. The other major mineral is plagioclase $\left(\mathrm{An}_{45}\right)$, which occasionally is quite strongly altered. Accessory minerals are opaques, biotite, apatite and zircon. The zircon is relatively coarse grained, as most crystals in the $70-150 \mathrm{~m}$ size fractions are obviously broken. From some crystals remaining intact, a minimum L/B ratio of 3 can be inferred. There is quite a strong oscillatory zoning, and generally the crystals are translucent. A few $(<1 \%)$ of darker, turbid crystals were removed during handpicking.

About $20 \mathrm{~kg}$ samples of both rock types were collected in a road cut along the Tampere-Huittinen highway (map sheet 211206, northing 6796.10, easting 2432.00). While the quartzdiorite sample could be collected as representing a single, roughly cubic piece, the gabbro sample represents three elongate sections collected within $3 \mathrm{~m}$ from each other and about $10 \mathrm{~m}$ away from the quartzdiorite sample.

\section{The Kalliokari tonalite}

Sample A1245-Kalliokari (map sheet 114208, northing 6846.46, easting 1528.90) represents a light to medium grey amphibole-biotite tonalite. The average grain size is $2.5 \mathrm{~mm}$, but in porphyritic varieties plagioclase may occur as $8 \mathrm{~mm}$ phenocrysts in a foliated groundmass that is phaneritic and granoblastic. Plagioclase is andesine $\left(\mathrm{An}_{35}\right)$, and in the porphyritic varieties it is weakly zoned, with more albitic rims. In the least deformed and altered tonalites the prominent mafic mineral is a light green or brown amphibole, which occasionally has pyroxene remnants in the core. With increasing deformation and alteration the biotite becomes more abundant in the tonalite and the mineral composition approaches trondhjemitic.

The tonalite has two prominent foliations (local $S_{1}$ and $S_{2}$ ) and a strong intersection lineation $\left(L_{2}\right)$. It hosts enclaves consisting of gneissic fragments of mafic igneous rocks, amphibolites and biotite- 
plagioclase gneiss, and rare peridotite. $\mathrm{A}_{3}$ deformation has deformed the tonalite into an augen mylonite northwards from the sample location in a major fault zone that cuts the earlier foliations can and be traced over hundreds of kilometres. Towards the south, in the Pori Shear Zone, the $\mathrm{D}_{3}$ deformation has occurred at more elevated temperatures, thus deforming the tonalite into a veined gneiss (Pietikäinen, 1994).

The zircons extracted from the rock are light brown and generally translucent, although rather turbid crystals occur especially in the 4.3-4.5 $\mathrm{g} / \mathrm{cm}^{3}$ fraction. The crystal habit is euhedral, with simple prismatic and pyramidal faces dominating. The length/breadth ratio varies from 1.5 to 3 with a median at about 2 . Under oil immersion, strong oscillatory zoning can be observed.

\section{Tonalites in the Evijärvi map sheet area}

In the western part of the Evijärvi map sheet (2314) there occur four smallish tonalite bodies surrounded by metasedimentary rocks. The rock is medium-to coarse-grained and orientated, and varies from dark to pale grey in colour. The major minerals are plagioclase, quartz, biotite and occasional hornblende. Locally, there occur mica-rich enclaves of varying $(3-15 \mathrm{~cm})$ sizes, which were avoided during sampling. Two samples, A1153-Kalliokangas (map sheet 231405, northing 7028.75, easting 2470.44) and A1242Purmojärvi (231402, 7022.51, 2461.38) were taken for analysis.

Both samples contained a fair amount of dark brown, almost euhedral zircon. The L/B of the zircons from A1153 vary between 2 and 3 for most of the sample. About $20 \%$ are longer, with the L/B ranging from 3 to 5 . The zircons exhibit oscillatory zoning, commonly thought to reflect a magmatic origin. No cores or inclusions were detected under oil immersion. The zircons from A1242 are slightly longer, with L/B from 2 to 5 (median 3.5), but resemble otherwise those from A1153. A1153-Kalliokangas contained also titanite, which was analyzed, too.

\section{ANALYTICAL METHODS AND RESULTS}

The samples were crushed and reduced to about $10 \%$ of the original size on a Wilfley table, and the heavy minerals were extracted by means of methylene diodide and Clerici's solution. The final purification of the zircon fractions was carried out by handpicking under a stereoscopic microscope. The samples were dissolved in teflon bombs and lead and uranium were purified by anion exchange chromatography according to the method of Krogh (1973). Mass-spectrometric analyses were carried out with a VG Sector 54 instrument. Data reduction was done with the Isoplot programme (Ludwig 1988).

The results for the Keikyä breccia are summarized in Table 1 and Figure 2.a. The two relatively concordant analyses from the brecciating gabbro demonstrate, as expected, a 1885-1890 Ma age for this particular rock. In contrast, the zircons from the quartzdiorite form two distinct populations: analyses $\mathrm{A}$ and $\mathrm{E}$ representing the heavy fraction exhibit markedly higher ${ }^{207} \mathrm{~Pb} /{ }^{206} \mathrm{~Pb}$ ages than the other four analyses representing lighter fractions, which fall on a nearly linear trend (MSWD 3.4) intersecting the concordia curve at $1889 \pm 9$ and $408 \pm 144 \mathrm{Ma}$.

The results may be interpreted as indicating that the quartzdiorite fragments of the Keikyä breccia represent an intrusion, which was emplaced $1889 \pm 9 \mathrm{Ma}$ ago, and that this rock incorporated some older material into itself. Although the results for the gabbro matrix and the younger zircons from the quartzdiorite fragments overlap within experimental error, the position of the two gabbro zircon fractions on the concordia diagram relative to the discordia line of the quartzdiorite data suggest that the gabbro intrusion did not occur later than about $1885 \mathrm{Ma}$ ago.

The four zircon fractions analyzed from the Kalliokari tonalite (Table 2, Figure 2.b) exhibit three unabraded fractions yielding an almost perfect linear trend (MSWD 0.34) with an upper intercept age estimate at $1899 \pm 6 \mathrm{Ma}$. The fact that the abraded fraction A points to an older origin for some of the zircons and may be indicative of older inherited cores, which, however, have not been detected under optical studies. 
Table 1. U-Pb mineral data from the Keikyä breccia.

\begin{tabular}{|c|c|c|c|c|c|c|c|c|c|c|}
\hline \multirow[t]{2}{*}{ Sample } & \multirow[t]{2}{*}{ Fraction } & \multirow{2}{*}{$\begin{array}{l}\text { Uconc } \\
\mathrm{ppm}\end{array}$} & \multirow{2}{*}{$\begin{array}{l}\text { Pbconc } \\
\text { ppm }\end{array}$} & \multirow{2}{*}{$\begin{array}{l}206 / 204 \\
\text { meas. }\end{array}$} & \multirow{2}{*}{\multicolumn{2}{|c|}{$\begin{array}{l}206 / 238 \quad 207 / 235 \\
\text { Corrected for blank }\end{array}$}} & \multirow[t]{2}{*}{$207 / 206$} & \multicolumn{3}{|c|}{ Apparent age in $\mathrm{Ma}$} \\
\hline & & & & & & & & $6 / 8$ & $7 / 5$ & $7 / 6$ \\
\hline \multicolumn{11}{|c|}{ A1304-Granodiorite } \\
\hline A & $\begin{array}{l}+4.3 \\
\mathrm{abr} 2 \mathrm{~h}\end{array}$ & 487.0 & 168.11 & 5392 & .3340 & 5.407 & .1174 & 1857 & 1885 & 1917 \\
\hline B & $\begin{array}{l}4.2-4.3 \\
\text { abraded }\end{array}$ & 718.8 & 243.48 & 2270 & .3228 & 5.102 & .1146 & 1803 & 1836 & 1874 \\
\hline C & $\begin{array}{l}4.2-4.3 \\
+70 \mathrm{~m}\end{array}$ & 720.5 & 241.81 & 2816 & .3214 & 5.081 & .1147 & 1796 & 1833 & 1875 \\
\hline D & $\begin{array}{l}4.0-4.2 \\
+70 \mathrm{~m}\end{array}$ & 1093 & 342.76 & 1006 & .2869 & 4.466 & .1129 & 1625 & 1724 & 1847 \\
\hline E & $\begin{array}{l}+4.3 / \mathrm{abr} \\
\text { pale br. }\end{array}$ & 497.5 & 170.59 & 7470 & .3334 & 5.362 & .1166 & 1854 & 1878 & 1905 \\
\hline $\mathrm{F}$ & $\begin{array}{l}4.2-4.3 \\
\text { abr } 5 \mathrm{~h}\end{array}$ & 723.0 & 247.19 & 2236 & .3255 & 5.160 & .1150 & 1816 & 1846 & 1880 \\
\hline \multicolumn{11}{|c|}{ A1348-Hornblende gabbro } \\
\hline A & $+4.3 / \mathrm{abr}$ & 454.8 & 159.17 & 2612 & .3340 & 5.291 & .1149 & 1857 & 1867 & 1878 \\
\hline B & +4.3 & 434.8 & 147.50 & 8613 & .3291 & 5.206 & .1147 & 1834 & 1853 & 1875 \\
\hline
\end{tabular}

Common lead correction ${ }^{206} \mathrm{~Pb} /{ }^{204} \mathrm{~Pb}: 15.7 ;{ }^{207} \mathrm{~Pb} /{ }^{204} \mathrm{~Pb}: 15.3 ;{ }^{208} \mathrm{~Pb} /{ }^{204} \mathrm{~Pb}: 35.2$.

A

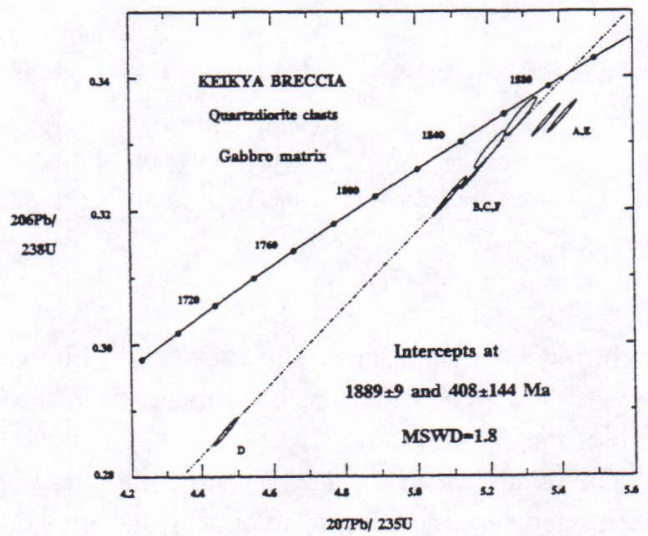

C

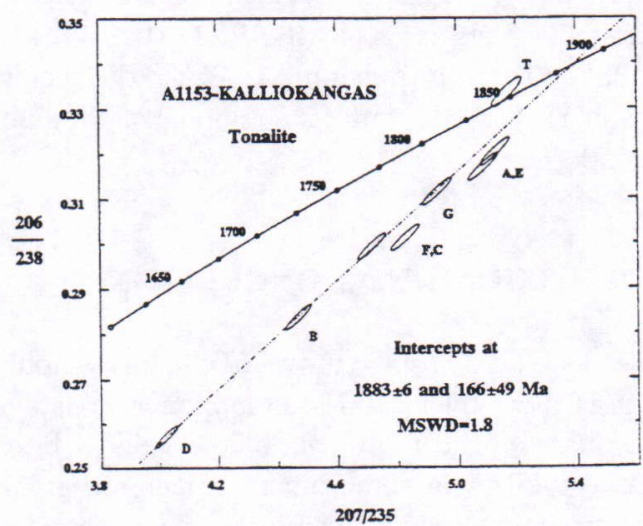

B

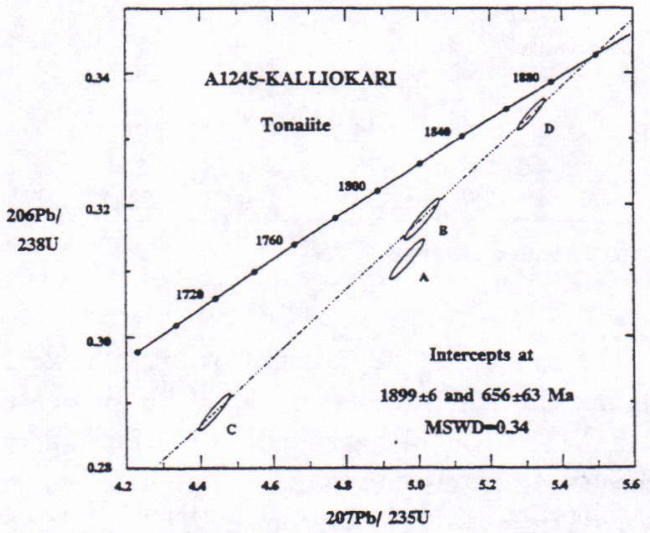

D

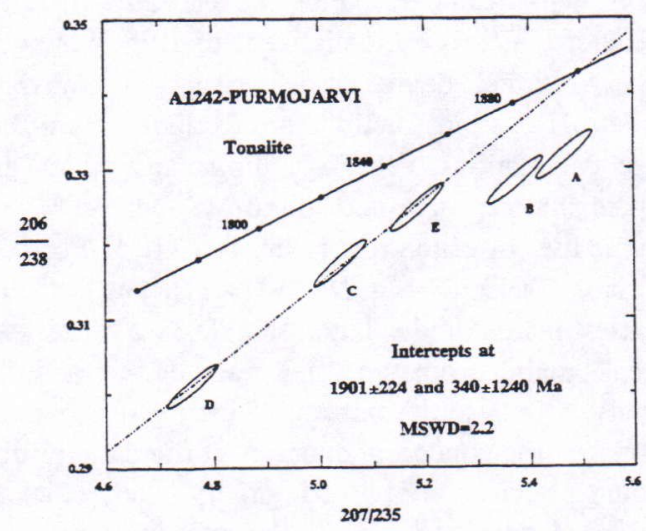

Figure 2. Concordia diagrams for the analyzed samples. a) The Keikyä breccia, filled ellipses indicate the matrix gabbro; b) the Kalliokari tonalite; c) the Kalliokangas tonalite, and; d) the Purmojärvi tonalite. 
Table 2. Heterogeneous $\mathrm{U}-\mathrm{Pb}$ zircon data from some granitoid rocks in Finland.

\begin{tabular}{|c|c|c|c|c|c|c|c|c|c|c|}
\hline \multirow[t]{2}{*}{ Sample } & \multirow[t]{2}{*}{ Fraction } & \multirow{2}{*}{$\begin{array}{l}\text { Uconc } \\
\text { ppm }\end{array}$} & \multirow{2}{*}{$\begin{array}{l}\text { Pbconc } \\
\text { ppm }\end{array}$} & \multirow{2}{*}{$\begin{array}{l}206 / 204 \\
\text { meas. }\end{array}$} & \multirow{2}{*}{\multicolumn{2}{|c|}{$\begin{array}{l}206 / 238 \quad 207 / 235 \\
\text { Corrected for blank }\end{array}$}} & \multirow[t]{2}{*}{$207 / 206$} & \multicolumn{3}{|c|}{ Apparent age in $\mathrm{Ma}$} \\
\hline & & & & & & & & $6 / 8$ & $7 / 5$ & $7 / 6$ \\
\hline \multicolumn{11}{|c|}{ A1153-Kalliokangas tonalite } \\
\hline A & $\begin{array}{l}4.3-4.5 \\
\text { abr } / 3 \mathrm{~h}\end{array}$ & 667.4 & 214.86 & 7607 & .3170 & 5.087 & .1164 & 1775 & 1833 & 1901 \\
\hline B & $4.3-4.5$ & 773.7 & 222.87 & 6005 & .2837 & 4.471 & .1143 & 1610 & 1725 & 1868 \\
\hline $\mathrm{C}$ & $4.2-4.3$ & 582.9 & 178.78 & 6664 & .3013 & 4.827 & .1162 & 1697 & 1789 & 1898 \\
\hline D & $4.0-4.2$ & 996.8 & 262.11 & 3937 & .2571 & 4.022 & .1135 & 1474 & 1638 & 1855 \\
\hline E & $\begin{array}{l}4.3-4.5 \\
a b r / 6 h\end{array}$ & 639.3 & 207.36 & 11593 & .3204 & 5.127 & .1161 & 1791 & 1840 & 1896 \\
\hline $\mathrm{F}$ & $\begin{array}{l}4.3-4.5 \\
\mathrm{Fm}\end{array}$ & 726.8 & 221.61 & 5436 & .2994 & 4.717 & .1143 & 1688 & 1770 & 1868 \\
\hline G & $\begin{array}{l}4.2-4.3 \\
\mathrm{~F} \mathrm{~m}\end{array}$ & 545.9 & 173.42 & 5762 & .3116 & 4.934 & .1149 & 1748 & 1808 & 1877 \\
\hline $\mathrm{H}$ & titanite & 96.6 & 34.43 & 1370 & .3336 & 5.169 & .1124 & 1855 & 1847 & 1838 \\
\hline \multicolumn{11}{|c|}{ A1242-Purmojärvi tonalite } \\
\hline A & $\begin{array}{l}+4.3 \\
a b r / 3 \mathrm{~h}\end{array}$ & 580.1 & 194.87 & 10302 & .3317 & 5.470 & .1196 & 1846 & 1895 & 1950 \\
\hline B & +4.3 & 576.6 & 192.02 & 8313 & .3283 & 5.373 & .1187 & 1830 & 1880 & 1936 \\
\hline $\mathrm{C}$ & $4.2-4.3$ & 792.9 & 251.67 & 9536 & .3174 & 5.038 & .1151 & 1776 & 1825 & 1882 \\
\hline D & $4.0-4.2$ & 969.7 & 292.62 & 9186 & .3011 & 4.760 & .1146 & 1696 & 1777 & 1874 \\
\hline $\mathrm{E}$ & $\begin{array}{l}4.2-4.3 \\
\mathrm{abr} / 3 \mathrm{~h}\end{array}$ & 807.5 & 263.72 & 8634 & .3248 & 5.185 & .1158 & 1813 & 1850 & 1892 \\
\hline \multicolumn{11}{|c|}{ A1245-Kalliokari tonalite } \\
\hline A & $\begin{array}{l}4.3-4.5 \\
\text { abr/4h }\end{array}$ & 505.6 & 160.71 & 8372 & .3117 & 4.968 & .1156 & 1749 & 1813 & 1889 \\
\hline B & $4.2-4.3$ & 676.0 & 220.24 & 3815 & .3177 & 5.011 & .1144 & 1778 & 1821 & 1870 \\
\hline $\mathrm{C}$ & $4.0-4.2$ & 976.5 & 295.23 & 1541 & .2886 & 4.438 & .1115 & 1634 & 1719 & 1824 \\
\hline $\mathrm{D}$ & $4.3-4.5$ & 500.4 & 169.67 & 22272 & .3336 & 5.314 & .1155 & 1855 & 1871 & 1888 \\
\hline
\end{tabular}

Common lead correction: ${ }^{206} \mathrm{~Pb} /{ }^{204} \mathrm{~Pb} 15.7 ;{ }^{207} \mathrm{~Pb} /{ }^{204} \mathrm{~Pb} 15.4 ;{ }^{208} \mathrm{~Pb} /{ }^{204} \mathrm{~Pb} 35.2$.

The results for the Evijärvi tonalites (Table 2, Figures 2.c and 2.d) indicate that the zircons in both A1153-Kalliokangas and A1242-Purmojärvi are heterogeneous, i.e. the zircon populations are derived from two or more sources. The older fractions with the higher ${ }^{207} \mathrm{~Pb} /{ }^{206} \mathrm{~Pb}$ ages are generally heavier (i.e. less metamictized) than the younger ones, and their degree of discordancy is relatively small. If the old fractions are excluded from the age calculations, A1153-Kalliokangas yields an upper intercept age of $1883 \pm 6 \mathrm{Ma}(\mathrm{MSWD}=1.8$ ) while the corresponding figure for A1242-Purmojärvi is $1901 \pm 224 \mathrm{Ma}(\mathrm{MSWD}=2.2$ ). The high error estimate for the latter sample is a statistical freak arising from the small number of fractions analyzed and the proximity of the results to each other on the concordia diagram. If the data for the young fractions are pooled (strictly taken an invalid procedure), the result becomes $1891 \pm 9 \mathrm{Ma}$ (MSWD=3.7). The titanite from A1153 exhibits a slight reverse discordancy and its ${ }^{207} \mathrm{~Pb} /{ }^{206} \mathrm{~Pb}$ age, $1838 \pm 5 \mathrm{Ma}$ gives an accurate estimate for the closure of its $\mathrm{U}-\mathrm{Pb}$ system.

The results from the Evijärvi tonalites may be interpreted as indicating an intrusion age not higher than $1883 \pm 6 \mathrm{Ma}$, but they contain material, part of which is at least $1950 \mathrm{Ma}$ old (the ${ }^{207} \mathrm{~Pb} /{ }^{206} \mathrm{~Pb}$ age of fraction $\mathrm{A} 1242 \mathrm{~A}$ ). The titanite age of $1838 \pm 5 \mathrm{Ma}$, reflects a regional cooling un$\operatorname{der} 500^{\circ} \mathrm{C}$.

\section{DISCUSSION AND CONCLUSION}

The analytical results prove beyond any doubt that an older than 1900 Ma component exists in the quartzdiorite fragments of the Keikyä breccia, as well as in some other syntectonic granitoids encountered in the Finnish Svecofennian. Whether this is limited to a few zircons inherited 
from either assimilated sediments or igneous rocks, or whether a larger amount of pre-existing material has been absorbed by the quartzdiorite at Keikyä or its other contemporaneous counterparts, is an open question. Nor can this problem be easily resolved. So far, Sm-Nd whole rock work in southern Finland has not revealed any significant Archean input into the Svecofennian crust, and detection of a Paleoproterozoic precursor is beyond the capabilities of the method. Ion probe work on zircons could conceivably establish a fairly exact age for the inherited zircons, but would give no better indications on the relative amounts of juvenile and inherited components. Probably the best hope is statistical analysis of an integrated $\mathrm{U}-\mathrm{Pb}$ mineral and $\mathrm{U}-\mathrm{Pb}$, $\mathrm{Sm}-\mathrm{Nd}, \mathrm{Rb}-\mathrm{Sr}$ whole rock data base. However, although the isotopic coverage of southern Finland is uncommonly good by any standards, the existing information is insufficient for this purpose.

The present results from the Keikyä breccia and other granitoid rocks in southern and central Finland suggest that the Presvecokarelian protocrust probably has been rather extensive, and has served both as a basement and possibly also as a source for the Svecofennian metaturbidites. However, the protocrust was largely consumed during the Svecokarelian orogeny, and the only indications of its existence may be found as minor inherited zircon populations in granitoid rocks and in the detrital materials preserved in low and medium grade metasediments.

The best hope for establishing the geographical extent of the protocrust is to hunt for older zircon populations in the early and syntectonic granitoid rocks, analyse individual grains and their parts with SIMS apparatus and to combine these results with high quality isotopic data measured from whole rock samples.

ACKOWLEDGEMENTS: We thank the technical staff of the Geological Survey of Finland for their assistance given during the preparation of this short notice. Discussions with Dr. Hannu Huhma helped $M V$ in the assessment of the analytical data, and constructive criticism as well as the authorization for publication was given by the acting chief of the Department of Petrology, Dr. Kalevi Korsman. Also, the comments of two anomymous referees are greatly appreciated. 


\section{REFERENCES}

Claesson, S., Huhma, H., Kinny, P.D. and Williams, I.S. (1993) Svecofennian detrital zircon ages implications for the Precambrian evolution of the Baltic Shield. Prec. Res. 64, 109-130.

Häkli, T.A., Vormisto, K. and Hänninen, E. (1979) Vammala, a nickel deposit in layered ultramafite, southwest Finland. Econ. Geol. 74, 1166-1182.

Helovuori, O. (1979) Geology of the Pyhäsalmi ore deposit, Finland. Econ. Geol. 74, 1084-1101.

Huhma, H., Claesson, S., Kinny, P.D. and Williams, I.S. (1991) The growth of Early Proterozoic crust: new evidence from Svecofennian detrital zircons. Terra Nova 3, 175-179.

Huhma, H. and Lahtinen, R. (1993) Isotopic studies on early Svecofennian crust. Symp. "The Svecofennian Domain", Turku, Finland, August 2325, 1993, Abstr., 28.

Korsman, K., Hölttä, O., Hautala, T. and Wasenius $P$. (1984) Metamorphism as an indicator of evolution and structure of the crust in Eastern Finland. Geol. Surv. Finland Bull. 328, 40 p.

Krogh, T.E. (1973) A low-contamination method for hydrothermal decomposition of zircon and extraction of $\mathrm{U}$ and $\mathrm{Pb}$ for isotopic age determinations. Geochim. Cosmochim. Acta 37, 485-494.
Lahtinen, $R$. (1994) Crustal evolution of the Svecofennian and Karelian domains during 2.1-1.79 Ga, with special emphasis on the geochemistry and origin of 1.93-1.91 gneissic tonalites and associated suoracrustal rocks in the Rautalampi area, centrla Finland. Geol. Surv. Finland Bull. 378, 128 p.

Ludwig, K.R. (1988) ISOPLOT - A plotting and regression program for radiogenic isotope data for IBM-PC compatible computers. U.S. Geol. Surv. Open-File Rep. 88-557, 32 p.

Matisto, A. (1964) Keikyän breksiasta. Geologi 17, 68-69.

Matisto, A. (1976) Kallioperäkartta - Prequaternary rocks. Sheet 2112, Huittinen. Suomen geologinen kartta - Geological map of Finland 1:100,000. Geol. Surv. Finland.

Pietikäinen, K.J. (1994) The geology of the Paleoproterozoic Pori Shear Zone, southwestern Finland, with special reference to the evolution of veined gneisses from tonalitic protoliths. Unpublished Ph.D. thesis, Michigan Tech. Univ. 150 p.

Vaasjoki, M. and Sakko, M. (1988) The evolution of the Raahe-Ladoga zone in Finland: isotopic constraints. Geol. Surv. Finland Bull. 343, 7-32. 